\title{
PENGEMBANGAN PERANGKAT PEMBELAJARAN BERBASIS KECERDASAN MAJEMUK UNTUK MENINGKATKAN KEMAMPUAN BERPIKIR MATEMATIS
}

\author{
Fitri Andriani', Yerizon², I Made Arnawa ${ }^{3}$, Ali Asmar ${ }^{4}$ \\ 1,2,3,4 Program Magister Pendidikan Matematika, Universitas Negeri Padang. \\ Email:fa9011043@gmail.com
}

\begin{abstract}
ABSTRAK
Masalah yang ditemui di lapangan adalah kemampuan berfikir kritis matematis peserta didik yang belum optimal. Kemampuan berfikir kritis matematis peserta didik dapat ditingkatkan dengan menggunakan perangkat pembelajaran berbasis kecerdasan majemuk. Tujuan dari penelitian ini adalah untuk mengetahui proses dan hasil pengembangan perangkat pembelajaran berbasis kecerdasan majemuk dalam meningkatkan kemampuan berfikir matematis peserta didik. Jenis penelitian ini adalah penelitian pengembangan (Development Research). Model pengembangan yang digunakan adalah model Plomp yang terdiri dari tiga fase yaitu fase investigasi awal (preliminary research), fase pengembangan atau pembuatan prototype (development or prototyping phase), dan fase penilaian (assessment phase). Pada bagian ini hanya membahas penelitian pada investigasi awal (preliminary research). Instrument yang digunakan pada fase investigasi awal (preliminary research) adalah angket peserta didik, pedoman wawancara guru, catatan lapangan, lembar soal tes pendahuluan. Hasil analisis data pada fase investigasi awal (preliminary research) menunjukkan bahwa 1) rendahnya kemampuan berfikir kritis matematis, 2) kemampuan peserta didik bervariasi, 3) cara belajar peserta didik bervariasi, 4) perangkat yang digunakan guru kurang memfasilitasi peserta didik untuk meningkatkan kemampuan berfikir kritis matematis peserta didik, 5) kurang terlibatnya peserta didik dalam proses pembelajaran, 6) peserta didik sulit memahami Bahasa yang digunakan pada sumber belajar.
\end{abstract}

Kata Kunci: Kecerdasan Majemuk, Kemampuan berfikir kritis matematis

\begin{abstract}
The problem encountered in the field is that students' mathematical critical thinking skills are not satisfying yet. Students' mathematical critical thinking skills can be improved by using multiple intelligence-based learning tools. The purpose of this study was to determine the process and the results of the development of learning tools based on multiple intelligence in improving students' mathematical thinking skills. This is a development research. The development model used is the Plomp model which consists of three phases, namely the preliminary research phase, the development or prototyping phase, and the assessment phase. This thesis only discusses the preliminary research phase. The instruments used in this research are student questionnaires, teacher interview guidelines, field notes, preliminary test question sheets. The results of data analysis in the preliminary research phase showed that 1) there is a lack of mathematical critical thinking skills, 2) Students have various kinds of abilities, 3) There are differences in students' learning styles, 4) There is a lack of teaching tools used by the teacher so that the students are not able to improve their critical thinking mathematically, 5) there is lack of students participation in the learning process, 6) It is difficult for students to understand the language used in the learning resources.
\end{abstract}

Keywords: Multiple Intelligences, Mathematical and Critical thinking ability 


\section{PENDAHULUAN}

Matematika memiliki peranan yang sangat penting dalam perkembangan ilmu pengetahuan karena matematika dapat mendidik seseorang berpikir secara logis, rasional, kritis, dan percaya diri. Mengingat begitu pentingnya peranan matematika maka pembelajaran matematika diterapkan dari jenjang Sekolah Dasar sampai Perguruan Tinggi. Tujuan pembelajaran matematika, salah satunya adalah untuk meningkatkan kemampuan berfikir tingkat tinggi peserta didik.

Pada abad 21, paradigma Pendidikan mulai bergeser pada penguasaan softskill. Melalui kurikulum 2013, Pendidikan di Indonesia dilaksanakan untuk mengasah; (1) berfikir kritis dan pemecahan masalah; (2) kemampuan berkomunikasi dan berkolaborasi; (3) kreativitas dan inovasi; (4) literasi teknologi informasi dan komunikasi; (5) belajar kontekstual; dan literasi media dan informasi.

Kenyataannya kemampuan berfikir kritis matematis peserta didik belum optimal. Hal ini terlihat dari hasil penelitian terdahulu yang dilakukan oleh (Kusaeri, 2019), (Heri, 2018), (Raisa B. Gul, 2014), (Kim, 2014), (Martaida, 2017), (Anike, 2020), (Ali, 2012), dan (Leni, 2017). Hasil dari penelitian-penelitian tersebut menunjukkan bahwa kemampuan berfikir kritis matematis peserta didik masih rendah.

Rendahnya kemampuan berfikir kritis matematis peserta didik ini berpengaruh terhadap hasil belajar peserta didik. Hal ini terlihat dari hasil ulangan matematika sebagian dari peserta didik dalam satu kelas tidak tuntas, seperti yang terlihat pada tabel 1.1 berikut:

Tabel 1. Persentase Ketuntasan Ulangan Harian Semester 1 Kelas VII Tahun Ajaran 2020/2021

\begin{tabular}{llll}
\hline Sekolah & Jumlah & \multicolumn{2}{c}{ Persentase Ketuntasan $(\geq 70)$} \\
\cline { 3 - 4 } & $\begin{array}{l}\text { Peserta } \\
\text { Didik }\end{array}$ & Jumlah siswa & Persentase \\
\hline SMPN 26 Padang & 32 siswa & 9 siswa & 28,13 \\
\hline SMPN 34 Padang & 30 siswa & 8 siswa & 26,66 \\
\hline
\end{tabular}

Sumber: Guru Matematika SMPN 26 dan SMPN 34

Tabel 1 ini menunjukkan bahwa persentase ketuntasan ulangan harian kedua sekolah tersebut masih rendah. Peserta didik yang mencapai Kriteria Ketuntasan Minimum (KKM) belum mencapai $50 \%$.

Untuk menyelesaikan masalah tersebut, perlu dilakukan peningkatan dalam proses pembelajaran, salah satunya dengan menggunakan perangkat pembelajaran yang bisa membuat peserta didik aktif, kreatif, dan termotivasi untuk berfikir kritis matematis dalam pembelajaran matematika sehingga pelajaran matematika menjadi menyenangkan. Untuk itu hal yang dapat menunjang kegiatan pembelajaran peserta didik agar terlaksana dengan baik adalah dengan menggunakan RPP dan LKPD yang dapat meningkatkan kemampuan berfikir kritis matematis berbasis kecerdasan majemuk.

LKPD yang digunakan di sekolah belum cocok dengan siswa. Hal ini dikarenakan, pada LKPD yang biasa digunakan kecerdasan majemuk nya hanya satu saja yaitu kecerdasan logika matematis. Sedangkan, anak memiliki kecerdasan majemuk yang berbeda-beda.

Dalam pengembangan LKPD dibutuhkan kecerdasan majemuk. Kecerdasan majemuk adalah kemampuan untuk memecahkan persoalan dan menghasilkan produk dalam keahlian yang berbeda-beda pada situasi yang nyata. Ada yang belajarnya bisanya berdiskusi, ada yang sendiri, ada yang belajar dengan bergerak, ada yang belajar dengan menggunakan gambar, ada yang belajarnya dengan musik, dsb. Kemampuan yang dimiliki masing-masing anak tidaklah sama. 
Pada saat mewawancarai guru, guru tau kecerdasan majemuk itu penting. Hanya saja tidak pernah diterapkan dikarenakan kesulitan dalam pengaplikasiannya harus membuat perangkat terlebih dahulu. Adapun beberapa penelitian terdahulu membahas tentang kecerdasan majemuk yang dominan pada siswa diantaranya penelitian yang dilakukan oleh (Kurnia, 2017) dan (Miftachudin, Budiyoo, dkk,2015), mereka meneliti kecerdasan yang dominan dimiliki siswa adalah logika matematis, interpersonal, dan linguistic. (Ika Kurnia Sari, 2019), (Frieda Wijayanti, 2016), dan (Mujib dan Mardiah, 2017) mendapatkan hasil penelitian kecerdasan majemuk yang dominan pada siswa visual spasial, linguistic, dan logika matematis. Untuk itu, penulis telah menyebarkan angket kepada 30 orang siswa untuk melihat kemampuan yang lebih dominan ada pada siswa dan hasilnya: visual spasial, logika matematis, interpersonal, dan linguistic.

Kecerdasan merupakan sebuah potensi diri yang sudah melekat pada anak sejak lahir. Tingkat kecerdasan yang dimiliki setiap anak pun berbeda-beda. Perbedaan tingkat kecerdasan pada setiap anak dipengaruhi oleh beberapa faktor: keturunan, lingkungan, kematangan, pembentukan, minat, dan bakat.

Menurut (Jasmine, 2012) teori tentang kecerdasan majemuk merupakan salah satu perkembangan paling penting dan menjanjikan dalam pendidikan dewasa ini. Menurut teori kecerdasan majemuk tidak ada manusia yang bodoh, setiap manusia memiliki potensi kecerdasannya masing-masing. Melalui potensi kecerdasan majemuk yang dimiliki siswa, guru dapat menyusun perangkat pembelajaran yang mengakomodasi setiap kecerdasan majemuk siswa. Oleh karena itu dibutuhkan suatu upaya mengembangkan perangkat pembelajaran matematika berbasis kecerdasan majemuk guna mengakomodasi setiap kecerdasan siswa dalam belajar matematika sehingga diharapkan siswa menjadi menyenangi pembelajaran matematika.

Menurut (Sunendar, 2017) berawal dari pandangan bahwa seseorang yang memiliki prestasi rendah dalam mata pelajaran matematika sering kali dianggap sebagai orang kurang cerdas. Padahal setiap orang cerdas dengan caranya sendiri (Hoerr, 2000), hal ini sesuai dengan kecerdasan majemuk yang dikemukakan oleh Gardner (Moore, 2009) mengemukakan, "to maximize learning, planning must address learnig styles and multiple intelligences". Untuk memaksimalkan pembelajaran, perencana pembelajaran harus memperhatikan kecerdasan majemuk. Pendapat ini menekankan bahwa kecerdasan majemuk dapat diberdayakan dalam merencanakan pembelajaran untuk mencapai kompetensi yang diharapkan, termasuk dalam pembelajaran matematika. Untuk itu perencanaan pembelajaran hendaknya memperhatikan potensi kecerdasan yang dimiliki oleh siswa.

Dari pendapat di atas, dapat disimpulkan bahwa kecerdasan majemuk itu penting diterapkan dalam pembelajaran. Hal ini dikarenakan, seringkali siswa dianggap bodoh hanya karena tidak menguasai satu kecerdasan. Padahal sebenarnya setiap anak memiliki kecerdasannya masing-masing. Misalnya, ada anak yang belajarnya dengan rumus, ada yang belajarnya dengan berkelompok, dengan gambar, dengan mendengar, dsb. Kecerdasan yang dimiliki masing-masing siswa sudah ada sejak lahir. Dan tidak bisa di ubah. Jika hal ini dibiarkan, maka kecerdasan yang dimiliki oleh masing-masing siswa tidak tersalurkan. Sehingga, siswa tersebut tetap dianggap bodoh. Dengan mengakomodasi kecerdasan majemuk dalam pembelajaran, maka bisa dijadikan wadah untuk menyalurkan kecerdasan yang berbedabeda pada siswa.

\section{METODE}

Jenis penelitian yang dilakukan adalah penelitian pengembangan (Development Research). Pengembangan merupakan metode penelitian untuk menghasilkan suatu produk dan menguji kevalidan, praktis, dan keefektifannya. Penelitian ini berguna untuk mengembangkan suatu produk berupa LKPD dan RPP berbasis kecerdasan majemuk untuk 
meningkatkan kemampuan berfikir kritis matematis peserta didik kelas VII SMP. Perangkat yang dikembangkan yaitu perangkat yang valid, praktis, dan efektif.

Model pengembangan yang digunakan adalah model Plomp yang terdiri dari tiga fase yaitu fase investigasi awal (preliminary research), fase pengembangan atau pembuatan prototype (development or prototyping phase), dan fase penilaian (assessment phase). Pada fase investigasi awal (preliminary research) peneliti melakukan tiga kegiatan yaitu analisis kebutuhan, analisis peserta didik, analisis kurikulum, dan analisis konsep. Setelah semua kegiatan tersebut selesai dilanjutkan pada fase pengembangan atau pembuatan prototype (development or prototyping phase), aktivitas yang dilakukan pada fase ini adalah pembuatan perangkat atau pengembangan perangkat pembelajaran yang akan diujicobakan dan revisi secara evaluasi sendiri dan tinjauan ahli. Hasil yang diperoleh pada fase ini dilanjutkan pada fase penilaian (assessment phase) kegiatan yang dilakukan adalah menilai kepraktisan dan keefektifan perangkat pembelajaran yang telah dikembangkan.

\section{HASIL DAN PEMBAHASAN}

Pada fase investigasi awal (preliminary research) dilakukan untuk tujuan mengetahui permasalahan yang terdapat dalam proses pembelajaran dan mengetahui hal-hal yang dibutuhkan untuk perangkat pembelajaran yang akan dikembangkan pada siswa SMP Kelas VII. Adapun fase investigasi awal (preliminary research) terdiri dari tiga kegiatan diantaranya:

a. Analisis Kebutuhan

Pada tahap analisis kebutuhan, informasi diperoleh dengan menggunakan pedoman wawancara guru, catatan lapangan, angket peserta didik, angket kecerdasan majemuk, dan lembar soal tes pendahuluan. Berdasarkan hasil pedoman wawancara guru diperoleh informasi bahwa kendala yang dialami guru adalah pembelajaran pada masa pandemi dengan daring membawa dampak buruk pada kemampuan berfikir kritis matematis siswa. Guru juga mengetahui pentingnya menerapkan kecerdasan majemuk pada saat pembelajaran oleh siswa di sekolah. Hanya saja tidak pernah diterapkan dikarenakan kesulitan dalam pengaplikasiannya, harus membuat perangkat pembelajaran terlebih dahulu.

Dalam proses pembelajaran selama ini guru menggunakan buku paket dan LKPD sebagai sumber belajar. LKPD yang digunakan bukanlah LKPD yang dibuat sendiri oleh guru tersebut. LKPD membantu peserta didik memahami materi tetapi tetap dijelaskan oleh guru terlebih dahulu. Namun, LKPD yang digunakan belum memfasilitasi peserta didik mengembangkan kemampuan berfikir kritis matematis karena belum terdapat langkah-langkah yang menuntun peserta didik untuk berfikir kritis dengan baik.

Berdasarkan pengamatan peneliti saat proses pembelajaran berlangsung adalah kurangnya terlibat peserta didik dalam proses pembelajaran. Peserta didik yang merespon aktif mengerjakan soal di depan kelas orangnya itu-itu aja. Apabila ada hal yang tidak dipahami, peserta didik lebih memilih bertanya kepada temannya daripada bertanya langsung dengan guru.

Dari angket yang diberikan kepada peserta didik juga diperoleh informasi bahwa peserta didik menganggap matematika adalah pelajaran yang sulit dan tidak menyenangkan. Namun, mereka menyadari bahwa matematika memiliki banyak manfaat. Selanjutnya, berdasarkan hasil angket kecerdasan majemuk yang dominan pada siswa, peneliti menemukan 4 kecerdasan yang dominan oleh siswa yaitu: kecerdasan logis matematis, kecerdasan linguistic, kecerdasan interpersonal, dan kecerdasan visual spasial.

b. Analisis Peserta Didik

Analisis peserta didik berguna untuk mengetahui dasar untuk merancang perangkat pembelajaran yang akan dikembangkan. Mengetahui kemampuan akademis peserta didik, mengetahui lingkungan peserta didik, bentuk pembelajaran yang disukai, LKPD yang diinginkan, serta kecerdasan yang dominan pada peserta didik. 
Peserta didik dalam satu kelas memiliki kemampuan akademis yang beragam antara lain peserta didik berkemampuan tinggi, sedang, dan rendah. Peserta didik Sebagian besar berdomisili di pinggir pantai dan dekat pasar. Hal ini seharusnya membuat peserta didik berani mengungkapkan pendapatnya saat belajar. Namun, kenyataannya peserta didik lebih memilih bertanya kepada teman daripada ke guru.

Bentuk pembelajaran yang disenangi peserta didik adalah secara berkelompok. Mengenai LKPD yang disukai peserta didik adalah LKPD bergambar, warna menarik, ukuran tetap ukuran LKPD yang biasanya, mudah dipahami. Warna yang dominan disukai peserta didik adalah warna biru.

Masing-masing siswa memiliki kecerdasan yang berbeda-beda dalam proses pembelajaran. Oleh karena itu, peneliti memberikan angket kecerdasan majemuk kepada siswa. Hasil dari analisis angket kecerdasan majemuk siswa dapat dilihat pada tabel berikut:

Tabel 2. Analisis Kecerdasan yang doinan dimiliki siswa

\begin{tabular}{lll}
\hline \multicolumn{1}{c}{ Kecerdasan } & Skor $>\mathbf{2 7}$ & $\mathbf{\%}$ Kecerdasan \\
\hline Logika Matematika & 19 siswa & $63 \%$ \\
\hline Visual Spasial & 16 siswa & $53 \%$ \\
\hline Kinestetik & 10 siswa & $33 \%$ \\
\hline Interpersonal & 21 siswa & $70 \%$ \\
\hline Intrapersonal & 10 siswa & $33 \%$ \\
\hline Musik & 7 siswa & $23 \%$ \\
\hline Naturalis & 3 siswa & $10 \%$ \\
\hline Eksistensial & 3 siswa & $10 \%$ \\
\hline Linguistik & 12 siswa & $40 \%$ \\
\hline
\end{tabular}

Dari perolehan data di atas, dapat disimpulkan bahwa kecerdasan majemuk yang dominan di miliki oleh siswa adalah:

$\begin{array}{ll}\text { a. } & \text { Logika Matematika } \\ \text { b. } & \text { Visual Spasial } \\ \text { c. } & \text { Interpersonal } \\ \text { d. } & \text { Linguistik }\end{array}$

\section{c. Analisis Kurikulum}

Sesuai dengan hasil wawancara dengan guru matematika SMPN 26 Padang, materi terakhir dan kurang dipahami siswa kelas VII Semester II adalah materi penyajian data. Untuk itu, peneliti tertarik untuk memilih materi penyajian data pada penelitian ini. Peneliti bersama guru juga sudah melakukan analisis KD dan analisis indicator. Untuk analisis kompetensi dasar tidak ada yang berubah. Sementara untuk indicator, terdapat banyak perbedaan sebelum dan sesudah di analisis. Hal ini dikarenakan materi disesuaikan dengan kecerdasan majemuk siswa. Indikator sebelum di analisis

1. Mencermati penyajian data tentang informasi di sekitar yang disajikan dalam bentuk tabel dan diagram. Misal : koran, majalah, dan televisi.

2. Mencermati cara penyajian data dalam bentuk tabel, diagram garis, batang, dan diagram lingkaran.

3. Mengumpulkan informasi tentang jenis data yang sesuai untuk disajikan dalam bentuk tabel, diagram garis, batang, dan diagram lingkaran.

4. Menyajikan hasil pembelajaran tentang penyajian data dalam bentuk tabel, diagram garis, batang, dan diagram lingkaran.

Indikator setelah di analisis

1. Mengenal data dalam kehidupan sehari-hari.

2. Memahami cata pengumpulan data. 
3. Menyajikan data dalam bentuk tabel.

4. Mengenal diagram batang dan diagram garis.

5. Menyajikan data dalam bentuk diagram batang.

6. Menyajikan data dalam bentuk diagram garis.

7. Mengenal diagram lingkaran

8. Menyajikan data dalam bentuk diagram lingkaran.

Dari hasil analisis kurikulum, yang berubah adalah susunan materi yang di sajikan. Setelah di analisis materi yang disajikan lebih tertata dan tersusun rapi. Lebih teratur dalam pembahasan masing-masing materi pembelajaran.Misalnya terlebih dahulu mengenal data, cara pengumpulan nya, dan bentuk-bentuk penyajian data.

d. Analisis Konsep

Penelitian akan dilakukan pada materi penyajian data. Analisis konsep dilakukan dengan menentukan dan menyusun konsep materi penyajian data yang akan dipelajari secara sistematis.

Materi yang akan di buat adalah materi penyajian data. Hubungan materi dengan kecerdasan majemuk adalah dengan menerapkan aspek-aspek kecerdasan majemuk yang dominan pada siswa ke dalam materi penyajian data. Misalnya: siswa yang mempunyai kemampuan visual spasial lebih suka belajar dengan menggunakan gambar, maka pada materi penyajian data memasukkan gambar yang berkaitan dengan materi pembelajaran. Selain itu, anak yang memiliki kecerdasan logika matematika, suka belajar dengan menggunakan rumus, maka pada materi penyajian data juga memasukkan rumus-rumus matematika.

Bagi anak yang memiliki kecerdasan interpersonal, maka anak tersebut cenderung belajar dengan berkelompok, untuk itu pada materi penyajian data juga menerapkan pembelajaran berkelompok. Kemudian, bagi anak yang memiliki kecerdasan linguistik, maka anak tersebut cenderung belajar dengan menggunakan Bahasa, untuk itu pada materi juga menambahkan soal cerita.

\section{SIMPULAN DAN SARAN}

Masalah yang ditemui di lapangan adalah kemampuan berfikir kritis matematis peserta didik belum optimal. Salah satu solusi untuk meningkatkan kemampuan berfikir kritis matematis peserta didik adalah dengan mengembangkan perangkat pembelajaran berbasis kecerdasan majemuk. Perangkat yang akan dikembangkan yaitu RPP dan LKPD. Jenis penelitian ini adalah penelitian pengembangan. Dari hasil investigasi awal terdiri dari 3 analisis yaitu:

a. Analisis kebutuhan : tahap analisis kebutuhan, informasi diperoleh dengan menggunakan pedoman wawancara guru, catatan lapangan, angket peserta didik, angket kecerdasan majemuk, dan lembar soal tes pendahuluan.

b. Analisis kurikulum : dari analisis kurikulum, materi yang dipelajari siswa lebih mudah dipahami. Penyajian data : mengenal data, cara pengumpulan data, bentuk-bentuk penyajian data (diagram batang, diagram garis, dan diagram lingkaran).

c. Analisis peserta didik : Analisis peserta didik berguna untuk mengetahui dasar untuk merancang perangkat pembelajaran yang akan dikembangkan. Dari analisis peserta didik, kecerdasan majemuk yang dominan oleh siswa yaitu: kecerdasan logika matematis, kecerdasan visual spasial, kecerdasan interpersonal, dan kecerdasan linguistic.

d. Analisis konsep : Pada analisis konsep, membahas tentang hubungan materi dengan kecerdasan majemuk yang dimiliki oleh masing-masing siswa.

\section{DAFTAR RUJUKAN}


Finnajah, Mutammimah. (2016). Pengembangan Modul Fisika SMA Berbasis Multi Representasi guna Meningkatkan Pemahaman Konsep dan Hasil Belajar Peserta Didik Kelas XI IIs 2 SMA Negeri 1 Prembun Tahun Ajaran 2015/2016. Universitas Muhammadiyah.

Hoerr, T. R. (2000). Becoming a multiple intelligences school. Alexandria. ASCD

Jasmine, J. (2012). Metode Mengajar Multiple Intelligences. Bandung: Khaifa

Kartika Sari, A, dkk. (2017). The effectiveness of Problem-Based Learning Approach Based on Multiple Intelligences in Term of Student's Achievement, Mathematical Connection Ability, and Self-Esteem. Journal of Physics:Converence Series.

Kim, K. (2014). The relationship between problem solving ability, profesional self concept, and critical thingking disposition of nursing students, Namseoul University, International Journal of Bio-Science and Bio Technology. 6, Hal.131-142.

Kurnia, Novi Rini. (2017). "Pengembangan LKS Berbasis Multiple Intelligence Untuk Meningkatkan Kemampuan Berfikir Kritis Matematis Siswa Kelas VII SMP". Universitas Muhammadiyah Purworejo.

Kurnia Sari Ika. (2019). Literasi Matematika Siswa Dalam Menyelesaikan Masalah Soal PISA Konten SPACE And SHAPE Ditinjau Dari Kecerdasan Majemuk. Jurnal Ilmiah Pendidikan Matematika. . Vol 8. No. 2.

Kusaeri. (2019). "Pedagogical Beliefs about Critical Thingking among Indonesian Mathematics Pre-service Teachers". International Journal of Instruction.Vol 12, No.1.

Martaida, Taota dkk (2017). The Effect Of Discovery Learning Model On Student's Critical Thingking And Cognitive Ability In Junior High School. IQSR Journal of Research \& Method in Education (IQSR-JRME) e-ISSSN: 2320-7388, p-ISSN: 2320-737X Volume 7, Issue 6 Ver.1.

Miftachudin, dkk. (2015).Efektivitas Model Pembelajaran Two Stay Two Stray Dengan Tutor Teman Sebaya Dalam Pembelajaran Matematika Pada Materi Bangun Datar Ditinjau Dari Kecerdasan Majemuk Peserta Didik Kelas VII SMPN Di Kebumen Tahun Ajaran 2014. Jurnal Elektronik Pembelajaran Matematika. Vol 3. No.3. hal 233-241.

Moore, K.D. (2009). Effective Instructional Strategies. London: SAGE Publications.

Mujib, dkk. 2017. Kemampuan Berfikir Kritis Matematis Berdasarkan Kecerdasan Multiple Intelligences. Jurnal Pendidikan Matematika. Vol.8. No.2.

Mulyanto, Heri, dkk. (2018). "The Effect of Problem Based Learning Model On Student Mathematics Learning Outcomes Viewed from Critical Thingking Skills. International Journal Of Education. 1-9.

Napitupulu, E.E, dkk. (2014). Peningkatan Kemampuan Berfikir Kritis Matematis dan Kemandirian Belajar Siswa SMP melalui Pembelajaran Berbasis Masalah. Jurnal Kreano. 157-169.

Noordyana, Mega Achdisty. (2016). Meningkatkan Kemampuan Berfikir Kritis Matematis Siswa Melalui Pendekatan Metacognitive Instruction. Jurnal Pendidikan Matematika STKIP Garut. 28-3 5.

Putri, Anike. (2020). "Development of Learning Tools with the Discovery Learning Model to Improve the Critical Thingking Ability of Mathematics. Journal Of Educational Sciences. Vol.4 No.1.

Raisa B. Gul, dkk. (2016). "Enhancing Educators' Skills for Promoting Critical Thingking in Their Classroom Discourses: A Randomized Control Trial". International Journal of Teaching and Learning in Higher Education.

Sunendar, Aep. (2017). Perangkat Pembelajaran Matematika Berbasis Teori Kecerdasan Majemuk Apa dan Bagaimana Mengembangkannya. Jurnal THEOREMS. Vol. 1. No. 2. 
Wijayanti, Frieda. (2015). Pengembangan LKS IPA Berbasis Multiple Intelligences pada Tema Energi dan Kesehatan untuk Meningkatkan Kemampuan Berfikir Kreatif Siswa. Universitas Negeri Semarang. 